\title{
PENGARUH COOPERATIVE LEARNING DIPANDU INQUIRY TERHADAP KEMAMPUAN BERPIKIR KRITIS SISWA SMA BERKEMAMPUAN ATAS DAN BAWAH DI KOTA METRO
}

\author{
Handoko Santoso \\ Pendidikan Biologi FKIP Universitas Muhammadiyah Metro \\ E-mail:hanbio@gmail.com
}

\begin{abstract}
The purpose of this research is to know the influence of biology teaching through inquiry integrated with cooperative towards the critical thinking ability. This research addresses the role of inquiry and cooperative learning strategy as well as these interactions towards the increase of the critical thinking ability. Quasi experimental research of Pretest-postest nonequivalent control group design with factorial design $2 \times 2 \times 2$ were implemented on the odd semester in academic years of 2006/2007 on X grade student of the state SMA in Metro City Lampung. The research sample consists of 96 students, comprising of student from high and low academic abilities. To examine hypothesis, it is used Ancova technique and continued by LSD test. There was a difference on the critical thinking ability between students who learn by inquiry level 1 with student who learn by inquiry level 2 , between students, who have high academic ability and students who have low academic ability, and there was not difference on the critical thinking ability between students who learn by STAD cooperative with student who learn by TPS. There is no effect of interaction between inquiry with cooperative, inquiry with student's academic ability, cooperative with student's academic ability, inquiry with cooperative and student's academic ability towards the cognitive achievement
\end{abstract}

Kata kunci: cooperative learning, inquiry, berpikir kritis

Pendidikan berbasis kompetensi menekankan pada kemampuan yang harus dimiliki oleh lulusan suatu jenjang pendidikan. Kompetensi yang sering disebut standar kompetensi lulusan adalah kualifikasi kemampuan lulusan yang mencakup sikap, pengetahuan, dan keterampilan (Depdiknas, 2005). Melalui pendidikan berbasis kompetensi diharapkan menghasilkan lulusan yang mampu berkompetisi di tingkat global. Kompetensi dapat dikenali melalui sejumlah hasil belajar dan indikatornya yang dapat diukur dan diamati, kompetensi dapat dicapai melalui pengalaman belajar yang dikaitkan dengan bahan pelajaran secara kontekstual (Depdiknas, 2002). Pengetahuan diperoleh melalui aktivitas belajar (Nur dan Muchlas,
1996). Perkembangan pengetahuan anak tergantung pada seberapa jauh anak aktif memanipulasi dan berinteraksi dengan lingkungan. Sehubungan dengan itu, maka dalam pembelajaran harus memusatkan perhatian pada berpikir atau proses mental anak dan mengutamakan peran siswa dalam berinisiatif serta keterlibatannya dalam kegiatan pembelajarannya. Trilling dan Hood (1999) menyebutkan beberapa ciri pembelajaran yang diharapkan terjadi pada era pengetahuan ini di antaranya guru sebagai fasilitator, pembelajaran berpusat pada siswa, dan kerjasama. Siswa harus membangun pengetahuan di dalam benaknya sendiri.

Pendidikan hendaknya direncanakan dan dilaksanakan dengan 
mengacu pada 4 pilar pendidikan UNESCO yaitu 1) belajar untuk mengetahui, 2) belajar untuk berbuat, 3) belajar untuk hidup bersama, dan 4) belajar menjadi seseorang (diri sendiri). Berdasar pada 4 pilar pendidikan tersebut, maka menjadi penting untuk mengembangkan kemampuan berpikir kritis siswa. Mengembangkan kemampuan berpikir kritis penting untuk menyelesaikan suatu masalah, dan hal ini berarti belajar untuk mengetahui dan berbuat (pilar 1 dan 2). Apabila kemampuan berpikir kritis tidak dikembangkan dengan baik, akan menyebabkan kualitas SDM semakin rendah, pada akhirnya tidak mampu hidup sejajar dengan bangsa lain. Mutu pendidikan Indonesia masih rendah, seperti diindikasikan oleh skor ujian akhir nasional yang rendah, juga digambarkan pada Human Development Index (HDI) yang salah satu indikatornya adalah pendidikan, Indonesia menduduki peringkat 102 dari 106 negara.

Sehubungan dengan kondisi ini perlu ada jalan keluar untuk mengatasinya. Salah satu upaya yang dapat dilakukan adalah dengan memilih dan menerapkan strategi pembelajaran yang tepat, sehingga proses pembelajaran berlangsung optimal yang mampu mengembangkan kemampuan berpikir kritis. Proses pembelajaran sangat penting peranannya dalam pencapaian tujuan pendidikan, di antaranya kemampuan berpikir kritis. Melalui proses pembelajaran yang baik dan tepat, akan diperoleh kemampuan berpikir rkitis yang baik juga. Proses pembelajaran yang baik, di antaranya dicirikan oleh keterlibatan aktif siswa dalam belajarnya dan terjadinya kerjasama, bertujuan mengembangkan kemampuan akademik dan kecakapan sosial. Pembelajaran inquiry dengan cooperative learning diharapkan dapat dijadikan sebagai alternatif untuk mewujudkan proses pembelajaran yang demikian. Dari uraian di atas, maka perlu dilakukan kajian secara mendalam melalui penelitian. Perlu diteliti peran cooperative learning dan inquiry, serta interaksi keduanya terhadap peningkatan kemampuan berpikir kritis. Selain itu, perlu diteliti peran tersebut pada siswa berkemampuan akademik atas dan bawah.

\section{METODE}

Perlakuan (treatment) dalam penelitian ini berupa setting atau skenario pembelajaran sebagai variable bebas, yaitu pembelajaran inquiry yang dilaksanakan dengan strategi kooperatif. Ada 4 macam setting pembelajaran, yaitu pendekatan inquiry tingkat 1 dengan cooperative learning tipe STAD, inquiry tingkat 1 dengan cooperative learning tipe TPS, inquiry tingkat 2 dengan cooperative learning tipe STAD, dan inquiry tingkat 2 dengan cooperative learning tipe TPS. Keempat setting pembelajaran ini dalam analisisnya akan dilihat pengaruhnya terhadap variabel terikat kemampuan berpikir kritis baik pada kelompok siswa berkemampuan akademik atas maupun bawah. Adapun desain penelitian ini adalah: "PretestPostest Non-equivalent Control Group Design", menggunakan rancangan faktorial 2 × 2 × 2 .

Populasi penelitian adalah siswa kelas X SMA di Kota Metro Lampung Tahun Pelajaran 2006/2007. Penentuan sampel ditempuh langkah sebagai berikut. Tahap pertama menentukan sekolah yang akan digunakan sebagai tempat penelitian dengan mempertimbangan kesetaraan peringkatnya, yaitu SMAN 2 dan SMAN 3 Metro Lampung. Kelas yang digunakan dalam penelitian ditentukan secara acak, dipilih 2 kelas pada setiap sekolah, sehingga berjumlah 4 kelas. Dari 4 kelas ini ditentukan 
secara acak untuk menerapkan skenario pembelajaran yang berbeda. Adapun sampel sebanyak 96 siswa yang meliputi siswa berkemampuan atas dan siswa berkemampuan bawah yang berada pada 4 kelas tersebut. Setiap kelas diambil $33,3 \%$ (12 siswa) berkemampuan atas dan 33,3\% (12 siswa) berkemampuan bawah. Pengelompokan kemampuan siswa ini didasarkan pada nilai Ujian Akhir Nasional SMP. Satuan analisisnya siswa

Instrumen yang digunakan untuk mengukur variabel terikat berupa tes. Pengumpulan data dilakukan dengan memberikan tes awal dan tes akhir. Tes awal dan tes akhir menggunakan instrumen yang sama. Pengujian hipotesis dilakukan dengan menggunakan Anacova yang dilanjutkan dengan uji beda LSD (Sujana, 1994; Sastrosupadi, 1994).. Analisis statistik ini dibantu dengan progran analisis statistik SPSS 12.0 for Windows, dilakukan dengan taraf signifikansi 0,05. Hasil pretes ditempatkan sebagai kovariat. Sebelum dilakukan uji analisis kovarian, dilakukan uji persyaratan normalitas dan uji homogenitas Hasil uji menunjukkan semua kelompok data berdistribusi normal dan varian antar data homogen.

\section{HASIL}

Ringkasan hasil analisis data disajikan pada Tabel 1 berikut.

Tabel 1. Hasil Analisis Data

\begin{tabular}{|l|l|l|}
\hline No & Variabel (pembelajaran) & Hasil Uji Hipotesis \\
\hline 1 & Inquiry & Signifikan \\
2 & Cooperative Learning & Tidak Signifikan \\
3 & Kemampuan akademik & Signifikan \\
4 & Interaksi cooperative learning dengan inquiry & Tidak Signifikan \\
5 & Interaksi inquiry dengan kemampuan akademik & Tidak Signifikan \\
6 & Interaksi cooperative learning dengan dengan kemampuan & Tidak Signifikan \\
7 & akademik & \\
\hline
\end{tabular}

\section{PEMBAHASAN}

\section{Pengaruh Pendekatan Inquiry terhadap Kemampuan Berpikir Kritis}

Hasil penelitian menunjukkan bahwa pendekatan inquiry berpengaruh nyata terhadap kemampuan berpikir kritis siswa. Kemampuan berpikir kritis siswa yang belajar dengan pendekatan inquiry tingkat 2 lebih tinggi jika dibandingkan dengan kemampuan berpikir kritis siswa yang belajar dengan pendekatan inquiry tingkat 1. Hasil penelitian ini mendukung hasil penelitian serupa terdahulu, Winarni (2006) dan Setiawan (2005) menyimpulkan pembelajaran inquiry terbimbing berpengaruh terhadap kemampuan berpikir kritis siswa. Skenario pembelajaran inquiry mengajak siswa melakukan serangkaian kegiatan fisik maupun mental (kognitif). Siswa diminta untuk memahami atau 
merumuskan: masalah, tujuan, dan hipotesis. Siswa melakukan pengamatan atau penyelidikan, mencari data, menganalisis uantuk menjawab permasalahan yang telah dirumuskan. Aktivitas yang dilakukan siswa ini akan mengembangkan kemampuan berpikir kritis siswa. Inquiry merupakan strategi pembelajaran yang menggunakan berpikir aktif siswa dan pemecahan masalah. Pembelajaran yang melibatkan kegiatan analisis masalah, penyusunan hipotesis, manipulasi variabel, mendesain dan melaksanakan penyelidikan dapat mengembangkan kemampuan berpikir tingkat tinggi siswa. Melalui pendekatan inquiry, maka siswa terlibat dalam kesempatan belajar dengan derajad self direction yang tinggi dan dapat menjaga serta menggunakan informasi untuk waktu yang lama (Ellis dalam Hambali, 2004).

Kemampuan berpikir kritis siswa yang belajar dengan inquiry tingkat 2 lebih tinggi jika dibandingkan dengan kemampuan berpikir siswa yang belajar dengan inquiry tingkat 1 . Hal ini dapat dipahami dari intensitas keterlibatan aktif siswa dalam inquirynya yang berbeda pada inquiry tingkat 2 dan inquiry tingkat 1 . Perbedaan intensitas keterlibatan siswa dalam belajarnya mempengaruhi peningkatan hasil belajar kemampuan berpikir kritis. Pada inquiry tingkat 1, keterlibatan siswa dalam inquiry lebih sedikit, keperluan untuk kegiatan inquiry sudah disiapkan oleh guru, siswa melakukan penyelidikan dan mengambil kesimpulan serta mempresentasikan hasilnya. Intensitas keterlibatan ini menyebabkan pengalaman belajar yang diperolehnya juga lebih sedikit. Pada inquiry tingkat 2, sedikit diberi oleh guru, sehingga siswa banyak terlibat aktif dalam belajarnya. Pada inquiry tingkat 2, keterlibatan siswa dalam inquiry lebih tinggi dari inquiry tingkat 1 , siswa diminta membuat prosedur kerja untuk kegiatan penyelidikan atau pengamatan. Kegiatan inquiry yang dilaksanakan siswa dalam pembelajarannya, mendorong siswa berpikir dan bekerja atas inisiatif sendiri (Brunner dalam Amin, 1988). Kebiasaan kegiatan ini dapat merangsang dan meningkatkan berpikir kritis pada siswa. Siswa dapat menemukan jawaban atas permasalahan yang dirumuskan. Melalui pembelajaran inquiry siswa terkondisi berpikir secara kritis untuk menemukan kesimpulan atas dasar observasi, pencarian jawaban yang dilakukan (Nagalsky, 1980). Senada dengan ini, Trautmann et al, (2000) menyatakan inquiry yang dilaksanakan secara kelompok dapat meningkatkan aktivitas belajar dan berpikir kritis.

Interaksi pendekatan inquiry dengan cooperative learning tidak berpangaruh nyata terhadap kemampuan berpikir kritis siswa. Tidak ada perbedaan nyata kemampuan berpikir kritis siswa sebagai akibat interaksi pendekatan inquiry dengan strategi kooperatif. Hasil ini juga bermakna bahwa inquiry tingkat 1 dan 2 yang dipadukan dengan cooperative learning tipe STAD atau TPS semuanya dapat meningkatkan kemampuan berpikir kritis.

Interaksi pendekatan inquiry dengan cooperative learning dan kemampuan akademik siswa menunjukkan bahwa interaksi ketiganya tidak berpengaruh nyata terhadap kemampuan berpikir kritis siswa. Tidak ada perbedaan nyata kemampuan berpikir kritis siswa sebagai akibat interaksi inquiry dengan kooperatif dan kemampuan akademik siswa. Walaupun interaksi tersebut tidak menunjukkan pengaruh nyata terhadap kemampuan berpikir kritis, namun perlu diungkapkan rata-rata kemampuan berpikir kritis terkoreksi pada kombinasi-kombinasi dari interaksi tersebut. Kombinasi 
inquiry tingkat 1 dengan kooperatif STAD pada kemampuan akademik atas memperoleh rata-rata kemampuan berpikir kritis berbeda nyata dan lebih tinggi dari kombinasi inquiry tingkat1 dengan kooperatif STAD pada kemampuan akademik bawah. Begitu juga kombinasi inquiry tingkatl dengan kooperatif TPS pada kemampuan akademik atas memperoleh rata-rata kemampuan berpikir kritis lebih tinggi dari kombinasi inquiry tingkat1 dengan kooperatif TPS pada kemampuan akademik bawah. Rata-rata kemampuan berpikir kritis pada kombinasi inquiry tingkat 2 dengan kooperatif STAD pada kemampuan akademik atas berbeda nyata dan lebih tinggi dari kombinasi inquiry tingkat1 dengan kooperatif STAD pada kemampuan akademik bawah, begitu juga rata-rata kemampuan berpikir kritis pada kombinasi inquiry tingkat 2 dengan kooperatif TPS pada kemampuan akademik atas lebih tinggi dari kombinasi inquiry tingkat 2 dengan kooperatif $S T A D$ pada kemampuan akademik bawah.

Temuan di atas juga mengandung makna bahwa perpaduan antara inquiry (tingkat 1 dan 2) dengan cooperative learning (tipe STAD dan TPS) samasama dapat meningkatkan kemampuan berpikir kritis baik pada siswa berkemampuan akademik atas maupun bawah. Sintaks pembelajaran paduan/gabungan inquiry (tingkat 1 dan 2) dengan cooperative learning (STAD dan TPS) terbukti dapat meningkatkan kemampuan berpikir kritis pada siswa berkemampuan akademik atas maupun bawah. Sintaks gabungan yang merupakan temuan dalam penelitian ini dapat diterapkan pada siswa berkemampuan akademik atas maupun bawah.

\section{Pengaruh Cooperative learning} terhadap Kemampuan Berpikir Kritis
Hasil analisis menunjukkan cooperative learning tidak berpengaruh nyata terhadap kemampuan berpikir kritis siswa. Tidak ada perbedaan nyata kemampuan berpikir kritis antara siswa yang belajar dengan cooperative learning tipe $S T A D$ dengan siswa yang belajar dengan kooperatif tipe TPS. Hasil ini juga berarti kooperatif $S T A D$ dan TPS memberikan sumbangan yang sama dalam meningkatkan kemampuan berpikir kritis. Kemampuan berpikir kritis dapat berkembang kalau sengaja dilatih dan dikembangkan. Mengembangkan kemampuan berpikir kritis memerlukan latihan dalam waktu yang cukup. Kemampun berpikir kritis akan mengalami perkembangan sesuai bentuk latihan dan tuntutan berpikirnya, untuk itu sekolah (pembelajaran) harus membelajarkan siswa berpikir (John Dewey dalam Ibrahim dan Nur, 2000). Johnson dan Johnson dari penelitiannya dalam waktu cukup lama baru memperoleh kesimpulan tentang penggunaan strategi penalaran tingkat tinggi pada saat kerja dalam kelompok kooperatif (Blosser, 1992). Menurut Vigotsky, interaksi sosial dengan teman lain melalui kerja kelompok memacu terbentuknya ide dan memperkaya perkembangan mental anak, sehingga membuat proses berpikir menjadi terbuka bagi seluruh anak (Ibrahim dan Nur, 2000).

Melalui kegiatan pembelajaran kooperatif, siswa dilatih untuk bekerja sama, berdiskusi, bertukar ide, saling mengungkapkan ide, saling memberi dan menerima untuk memperoleh jawaban suatu persoalan. Aktivitas-aktivitas dalam kelompok sebaya tersebut dapat menjadi sarana untuk meningkatkan kemampuan berpikir siswa. Siswa yang belum tahu akan berupaya mencari tahu, sedang siswa yang sudah tahu akan berupaya memberi tahu kepada 
kawannya yang memerlukan. Dengan demikian melalui kegiatan pembelajaran kooperatif dapat menyediakan situasi yang merangsang terlatihnya kemampuan berpikir kritis siswa (Shia et al dalam Arnyana, 2004). Pembelajaran dengan kooperatif tipe STAD dapat meningkatkan motivasi, berpikir kritis, hasil belajar, dan kepedulian atau kerjasama antar anggota kelompok (Qodriyah, 2002; Nornia, 1997; Arnyana, 2004; Nurhanurawati, 2003). Begitu juga kooperatif TPS, cooperative learning TPS pada pembelajaran pola pemberdayaan berpikir melalui bertanya (PBMP) dapat meningkatkan aktivitas belajar, kemampuan berpikir, dan hasil belajar (Sumarsih dkk, 2005; Suryani dkk, 2005).

Kooperatif tipe STAD dan TPS memiliki karakteritik yang berbeda. Dilihat dari sintaksnya, intensitas aktivitas berpikir lebih banyak pada TPS dari STAD. Pada TPS ada tahap dimana siswa diberi tugas untuk berpikir mandiri terhadap persoalan yang diberikan guru, baru kemudian didiskusikan dengan teman pasangannya. Pada kooperatif $S T A D$, persolan atau tugas dari guru langsung dikerjakan dalam forum kelompok. Pada sisi lain, intensitas interaki bekerja sama dengan teman sebaya, diskusi membahas materi untuk menyelesaikan tugas berlangsung lebih banyak pada tipe $S T A D$. Pada kooperatif tipe $S T A D$, interaksi siswa antar anggota kelompok berlangsung sejak kelompok menyelesaikan tugas. Selama menyelesaikan tugas itu interaksi dengan teman dalam kelompok sudah berlangsung, kemudian interaksi lebih luas lagi akan diteruskan pada saat diskusi kelas. Pada kooperatif TPS, interaksi berlangsung pada saat bekerja berpasangan, interakasi terjadi dengan pasangannya, tidak seperti pada $S T A D$ dengan kelompoknya 4-5 siswa. Pada TPS juga ada sharing, diskusi kelas, sehingga juga berlangsung interaksi dengan siswa seluruh kelas. Perbedaan pengalaman belajar siswa ini diduga menyebabkan perbedaan hasil belajar yang berupa kemampuan berpikir kritis, walaupun perbedaan itu tidak signifikan. Secara teoritis, sebagaimana diuraikan di atas, TPS lebih unggul mengembangkan kemampuan berpikir kritis dari pada $S T A D$, namun penelitian ini menemukan yang sebaliknya. Hal ini diduga disebabkan kesiapan siswa untuk berpikir dan belajar mandiri masih kurang. Siswa kelas X ini masih terbiasa menjalani pembelajaran berpusat pada guru, memilih untuk memperoleh penjelasan dari guru atau bantuan dari teman kelompoknya. Siswa belum terbiasa diajak belajar mandiri.

Interaksi cooperative learning dengan kemampuan akademik siswa menunjukkan tidak berpangaruh nyata terhadap kemampuan berpikir kritis siswa. Tidak ada perbedaan nyata kemampuan berpikir kritis siswa sebagai akibat interaksi antara cooperative learning dengan kemampuan akademik siswa. Hal ini juga mengandung makna bahwa cooperative learning tipe STAD dan TPS dapat diterapkan pada siswa berkemampuan akademik atas maupun bawah untuk meningkatkan kemampuan berpikir kritis.

\section{Pengaruh Kemampuan Akademik terhadap Kemampuan Berpikir kritis}

Hasil penelitian ini menunjukkan kemampuan akademik berpengaruh sangat nyata terhadap kemampuan berpikir kritis. Siswa dengan kemampuan akademik atas memiliki kemampuan berpikir kritis lebih tinggi jika dibandingkan dengan siswa yang memiliki kemampuan akademik bawah. Hasil ini sesuai dengan penelitian Winarni (2006); Tindangen (2006) yang menyimpulkan kemampuan akademik 
siswa berpengaruh pada kemampuan berpikir kritis. Pada siswa berkemampuan akademik atas lebih baik kemampuan berpikir kritisnya jika dibandingkan dengan siswa berkemampuan akademik bawah. Susantini (2004), melalui penelitiannya juga menyimpulkan kemampuan berpikir pada siswa berkemampuan akademik atas lebih tinggi jika dibandingkan kemampuan berpikir pada siswa berkemampuan bawah. Senada dengan ini, Presseisen dalam Costa et al, (1985) menyatakan kemampuan berpikir dasar yang dimiliki siswa sangat menentukan keberhasilan siswa dalam berpikir kritis.Pengetahuan yang sudah ada pada siswa menjadi dasar untuk mengembangkan kemampuan berpikir kritisnya. Pada siswa berkemampuan akademik atas berarti memiliki pengetahuan yang lebih baik dibandingkan dengan siswa berkemampuan akademik bawah. Hasil penelitian yang disebutkan di atas adalah melihat pada hasil akhir kemampuan berpikir kritis. Beberapa penelitian menunjukkan bahwa siswa berkemampuan bawah diuntungkan dengan cooperative learning STAD dan PBMB-TPS, siswa memperoleh peningkatan hasil belajar yang tinggi (Taufik, 2005; Qodriyah, 2002).

Banyaknya pengetahuan yang ada pada siswa akan menghantarkan siswa untuk mengembangkan kemampuan berpikir kritisnya. Kemampuan berpikir kritis ini lebih tinggi pada siswa berkemampuan akademik atas, yang memiliki pengetahuan lebih banyak dari siswa berkemampuan akademik bawah. Lawson (1992) juga melaporkan bahwa siswa yang memiliki kemampuan berpikir formal (dalam penelitian ini berkemampuan akademik atas), lebih mampu menggunakan kemampuan berpikir tingkat tinggi jika dibandingkan dengan siswa yang memiliki kemampuan berpikir konkrit (berkemampuan akademik bawah). Kronberg dan Griffin (2000) menyatakan pada setiap jenjang pendidikan seharusnya menitikberatkan pada pengembangan berpikir. Menurutnya, hal ini dapat dilakukan dengan memberi kesempatan pada siswa untuk berpikir dengan melakukan kegiatan yang menuntut kemampuan berpikir. Melalui aktivitas analisis yang berulang akan membantu siswa melakukan internalisasi materi yang kompleks dan juga dapat membantu mengembangkan tingkat berpikir kritis siswa.

Kemampuan berpikir kritis hanya akan berkembang apabila memang sengaja dikembangkan. Sayangnya, mengembangkan kemampuan berpikir ini belum banyak dilakukan oleh guru biologi terhadap siswanya (Corebima, 2000). Kegiatan pembejalaran yang direncakan dan dilaksanakan dengan baik untuk mengembangkan kemampuan berpikir, merupakan faktor yang sangat penting dalam hal ini. Berkaitan dengan ini, Corebima (1999) menyatakan bahwa jika ingin mendorong kemampuan berpikir, pelaksanaan pembelajaran dan evaluasinya harus dikelola secara sengaja untuk mendukung kepentingan itu. Oleh karena itu pembelajaran (biologi) harus direncanakan dengan sengaja untuk mengembangkan kemampuan berpikir kritis. Pembelajaran biologi dengan metode yang tepat diharapkan menjadi sarana pengembangan kemampuan berpkir kritis.Apalagi dalam era pengetahuan ini, kemampuan berpikir kritsi sangat diperlukan agar tidak ketinggalan oleh kemajuan zaman. Era pengetahuan di antaranya ditandai dengan munculnya masalah-masalah sulit. Kemampuan berpikir kritis diperlukan untuk memecahkan masalah-masalah sulit 
yang dihadapi dalam kehidupan seharihari.

\section{KESIMPULAN DAN SARAN}

\section{Kesimpulan}

Berdasarkan hasil dan pembahasan dalam penelitian ini terdapat perbedaan kemampuan berpikir kritis antara siswa siswa yang belajar dengan pendekatan inquiry tingkat 1 dengan yang belajar dengan pendekatan inquiry tingkat 2 . Siswa yang belajar dengan pendekatan inquiry tingkat 2 memperoleh rata-rata kemampuan berpikir kritis lebih tinggi dari siswa yang belajar dengan pendekatan inquiry tingkat 1. Siswa yang belajar dengan cooperative learning STAD memperoleh rata-rata kemampuan berpikir kritis tidak berbeda nyata dengan siswa yang belajar dengan cooperative learning TPS. Terdapat perbedaan kemampuan berpikir kritis antara siswa berkemampuan akademik atas dan siswa berkemampuan akademik bawah. Siswa yang memiliki kemampuan akademik atas memperoleh kemampuan berpikir kritis lebih tinggi dari siswa yang memiliki kemampuan akademik bawah. Tidak ada pengaruh interaksi antara pendekatan inquiry dengan cooperative learning, antara pendekatan inquiry dengan kemampuan akademik siswa, antara cooperative learning dengan kemampuan akademik siswa, dan antara pendekatan inquiry dengan cooperative learning dan kemampuan akademik siswa terhadap kemampuan berpikir kritis.

\section{Saran}

Mengembangkan kemampuan berpikir kritis dalam pembelajaran sangat penting dilakukan. Guru biologi dapat menggunakan strategi pembelajaran inquiry dan strategi kooperatif, atau paduan keduanya. Unuk menerapkan pembelajaran inquiry yang dipadu dengan cooperative learning guru harus menyiapkan diri dengan baik, misalnya memahami benar skenario pembelajaran. Guru juga perlu memiliki peta kemampuan akademik siswanya, peta kemampuan ini antara lain digunakan dalam pembentukan kelompok kooperatif dan pemberian bimbingan dalam belajarnya.

\section{DAFTAR RUJUKAN}

Ardana, W. 2000. Reformasi Pembelajaran Menghadapi Abad Pengetahuan. Makalah disajikan dalam Seminar dan Diskusi Panel Nasional Teknologi Pembelajaran V. Diselenggarakan oleh Program Studi TEP PPS UM bekerjasama dengan Ikatan Profesi Teknologi Pendidikan Indonesia (IPTPI) Cabang Malang, 7 Oktober 2000.

Aryana. IBP. 2004. Pengembangan Perangkat Model Belajar Berdasarkan Masalah Dipandu Cooperative learning Serta Pengaruh Implementasinya Terhadap Kemampuan Berfikir Kritis dan Hasil Belajar Siswa Sekolah Menengah Atas Pada Pelajaran Ekosistem. Disertasi tidak diterbitkan. Malang: Program Pascasarjana Universitas Negeri Malang.

Callahan, J.F. Clark, L. H. Kellough, R.D. 1992. Teaching in The Middle and Secondary Schools. New York: Macmillan Publishing Company.

Corebima, A.D. 2002. Pemberdayaan Berpikir Melalui Pertanyaan (PBMP) Sebagai Alat Pembelajaran IPA-Biologi Konstruktivistik Untuk Meningkatkan Penalaran Siswa SLTP di Jawa Timur. Laporan Riset Unggulan Terpadu VIII Bidang Dinamika Sosial, Ekonomi dan 
Budaya. Malang: Lemlit Universitas Negeri Malang.

Depdiknas. 2005. Peraturan Pemerintah Republik Indonesia Nomor 19 Tahun 2005 Tentang Standar Nasional Pendikan. Jakarta: Depdiknas.

Ibrahim, M. 2002b. Teori Belajar Konstruktivisme. Jakarta: Direktorat Pendidikan Lanjutan Pertama. Direktorat Jenderal Pendidikan Dasar dan Menengah. Departemen Pendidikan Nasiona.

Nasution, S. 1988. Berbagai Pendekatan dalam Proses Belajar dan Mengajar. Jakarta: Bina Aksara.

Noornia, Z. 1997. Penerapan Pembelajaran Kooperatif dengan Metode STAD pada Pengajaran Persen di Kelas VI SD Islam Al Ma'arif 02 Singosari. Tesis Tidak Diterbitkan. Malang: Program Pascasarjana Universitas Negeri Malang.

Nurhanurawati. 2003. Penerapan Belajar Kooperatif Model STAD Dalam Pembelajaran Konsep Limit Barisan Pada Mahasiswa Matematika FKIP UNILA Lampung. Tesis tidak diterbitkan. Malang: Program Pascasarjana Universitas Negeri Malang

Nur, M. \& Muchlas, S. 1996. Teori Pembelajaran IPA dan Hakekat Pendekatan Keterampilan Proses. Jakarta: Depdikbud.

Qodriyah. 2002. Upaya Peningkatan Motivasi dan Hasil Belajar Biologi Melalui Pembelajaran Kooperatif (Tyoe STAD) Pada SMU Wahid Hasyim. Tesis tidak diterbitkan. Malang: Program Pascasarjana Universitas Negeri Malang.
Sunarsih. 2006. Penerapan TPS (ThinkPairs-Share) dalam Pembelajaran Berbasis Konstruktivis untuk Meningkatkan Proses Belajar Biologi Kelas X SMAN 2 Malang. Skripsi tidak diterbitkan. Malang: FMIPA Universitas Negeri Malang.

Susantini, E. 2004. Memeperbaiki Kualitas Proses Pembelajaran Genetika Melalui Strategi Metakognitif Dalam Pembelajaran Kooperatif Pada Siswa SMU. Disertasi. tidak diterbitkan. Malang: Program Pasasarjana UM Malang

Suyanto. 2005. Inovasi Pembelajaran. Makalah disajikan dalam acara Pelatihan Metodologi Penelitian Tindakan Kelas dan Penelitian untuk Peningkatan Kulaitas Pembelajaran, Direktorat Jendral Pendidikan Tinggi, Batam, 8-11 Agustus 2005.

Taufik. 2005. Upaya Meningkatkan Motivasi da Hasil Belajar Kimia Melalui Pembelajaran Kooperatif Model STAD pada MAN Rukoh Kota Banda Aceh. Tesis tidak diterbitkan. Malang: Program Pascasarjana Universitas Negeri Malang

Tindangen, M. 2006. Implementasi Pembelajaran Kontekstual Peta Konsep Biologi SMP pada Siswa Berkemampuan Awal Berbeda di Kota Malang dan Pengaruhnya terhadap Kemampuan Berpikir Tingkat Tinggi dan Hasil Belajar Kognitif. Malang: Disertasi tidak diterbitkan. Program Pascasarjana Universitas Negeri Malang

Trilling, B. \& Hood, P. 1999. Learning, Technology, and Education Reform in The Knowledge Age. Educational Technology. Mey-Juni; 5-18. 